\title{
A linhagem samba-bossa-MPB: sobre a construção de um discurso de tradição da música popular brasileira
}

\author{
Silvano Fernandes Baia (UFU, Uberlândia, MG) \\ silvanobaia@gmail.com
}

\begin{abstract}
Resumo: Este artigo apresenta um estudo acerca da construção dos discursos sobre música popular urbana no Brasil, desde o momento formativo dos primeiros textos historiográficos sobre o objeto, até a proposição da "linha evolutiva" e a institucionalização da MPB. Neste periodo, que vai da década de 1930 até o final dos anos 1960, constituiu-se uma linhagem da música popular no Brasil que tem como eixo central o samba carioca, em torno do qual formou-se um sistema sociocultural e um pensamento histórico-sociológico. A ideia desta linhagem, como articuladora da tradição da música popular brasileira, foi a concepção dominante sobre esta música até por volta dos anos 1980. Mesmo perdendo força e sendo submetida à crítica por pesquisas recentes, até hoje é um dos parâmetros para o debate sobre a produção e recepção da música no Brasil.
\end{abstract}

Palavras-chave: historiografia da música popular; história da música brasileira; samba e MPB.

\section{The samba-bossa-MPB lineage: on the construction of a discourse of Brazilian popular music tradition}

\begin{abstract}
This paper aims at presenting a study on the construction of discourses surrounding urban popular music in Brazil, from the formative moment with its first historiographical texts to the proposition of the "linha evolutiva" and the institutionalization of MPB (a segment of the Brazilian popular music). During this period, ranging from the 1930 to the 1960 decades, a lineage was established in the Brazilian popular music that had the samba from Rio de Janeiro as its central axis, around which a sociocultural system and a historical-sociological thought was constructed. The proposal of this lineage as the aforementioned axis of the Brazilian popular music tradition was a dominant idea about this kind of music until the 1980's. Although losing power and being submitted to criticism by recent studies, it remains as an important parameter for debate about music in Brazil.
\end{abstract}

Keywords: historiography of popular music; history of Brazilian music; samba and Brazilian MPB.

\section{1 - Introdução}

No momento em que surgiram os primeiros estudos acadêmicos sobre a música popular no Brasil, no início dos anos 1970, havia uma concepção tacitamente estabelecida, mas com ampla aceitação na sociedade, do que seria música popular brasileira. Ela era apreendida como uma linhagem desenvolvida em torno da música popular do Rio de Janeiro, que teve ampla circulação nacional através do rádio a partir da década de 1930, num momento em que se operava um complexo processo de construção de uma identidade nacional. Existiam também narrativas históricas nesta visão de senso comum de música popular brasileira, que incluiam concepções de nacionalidade e de autenticidade enquanto cultura popular, bem como um conjunto de autores e obras canônicas. Estas narrativas, que vinham se construindo a partir dos primeiros textos sobre música popular escritos nos anos 1930, tinham, portanto, algumas décadas de existência quando foram realizadas as primeiras pesquisa acadêmicas a tomar a música popular como objeto. Mesmo considerando-se os intensos debates estético-políticos ocorridos na década de 1960 e a modernização da linguagem musical a partir da Bossa Nova, ainda eram marginais aqueles que, como Raul Seixas, diziam não ter nada a ver com a linha evolutiva da música popular brasileira. ${ }^{1}$ 
Os ensaios acadêmicos dos anos 1970 e 1980 - incluindo tanto os artigos e livros voltados para uma circulação ampla, como os estudos pioneiros na pós-graduação através do rádio - ofereceram problemas, questões, abordagens e novos olhares para o fenômeno da música popular urbana que se constituíram em referências para a historiografia acadêmica que surgia. Na tese de doutorado A historiografia da música popular no Brasil (1971-1999) (BAIA, 2010), analisei detalhadamente 0 processo formativo de um pensamento historiográfico sobre música popular no Brasil, questão que já havia motivado estudos anteriores de outros pesquisadores do campo, entre os quais destaco os artigos de Arnaldo CONTIER (1991), José Geraldo Vinci de MORAES (2000, 2006 e 2007) e Marcos NAPOLITANO (2006 e 2007).

Os primeiros pesquisadores que tomaram a música popular como objeto de investigação científica, oriundos principalmente das áreas de Letras, Comunicação e Sociologia, depararam-se com a escassez e dificuldade de acesso às fontes primárias: os acervos públicos eram poucos e desorganizados e parte importante da documentação estava disponivel apenas em arquivos particulares. Assim, as pesquisas sobre música popular que estudaram os eventos das primeiras décadas do século $X X$, num primeiro momento, recorreram a fontes secundárias, narrativas de memorialistas e à historiografia de pesquisadores não acadêmicos. Como as narrativas e a própria seleção das fontes destes autores foram, em grande parte, orientadas por suas concepções estéticas e ideológicas, sua utilização como fonte e referencial privilegiado para outros estudos tendia a reproduzir e consolidar uma determinada leitura dos fatos, uma certa visão da história, por vezes sem a devida contextualização crítica. Por outro lado, o estudo dos eventos mais recentes, da segunda metade do século $X X$, para os quais as fontes estavam mais disponíveis, também ecoavam influências estético-ideológicas, uma vez que os pesquisadores geralmente tinham vínculos políticos ou afetivos com uma determinada corrente musical. 0 samba carioca da década de 1930, gênero central na construção de um discurso sobre música popular no Brasil, com confluências no pensamento social brasileiro, e a MPB dos anos 1960, que canalizou as lutas político-culturais daquele momento histórico, foram tomados como objetos privilegiados nos estudos pioneiros. Considere-se que, nestas pesquisas, foi se construindo uma metodologia, até então inexistente, para a abordagem da história da música popular, ou das relações entre música, história e sociedade, questão ainda não plenamente resolvida. Também o contexto no qual estes trabalhos foram realizados, momento de redemocratização do país após anos de regime militar, bem como o ambiente intelectual da Universidade brasileira, precisam ser considerados.

As visões então predominantes da história da música popular no Brasil, que vinham sendo construídas desde os anos 1930, reverberaram fortemente nas primeiras pesquisas acadêmicas. Porém, num processo contínuo de construção do conhecimento histórico, tais visões foram sendo sucessivamente submetidas à reflexão crítica quanto aos documentos e aos pressupostos estéticos e ideológicos em que se fundamentavam e foram sendo superadas por outros paradigmas interpretativos, especialmente com o início dos estudos sobre a música popular na área de História, a partir dos anos 1980, e na área de Música, a partir dos anos 1990. Novas pesquisas têm ampliado os horizontes e contribuído para uma maior compreensão da música no Brasil e da própria história política, social e cultural do país. Porém, as narrativas tradicionais ainda encontram eco em muitos discursos contemporâneos que ainda insistem em referenciarse numa bibliografia defasada em relação aos estudos mais recentes. É a partir desta perspectiva que este artigo apresenta um estudo do processo de formação da narrativa que se tornou senso comum em torno da ideia de música popular brasileira.

\section{2 - 0 legado dos musicólogos, memorialistas e primeiros historiadores da música popular no Brasil}

Duas linhas de força tensionam o entendimento da música no Brasil e projetam-se nos livros que contam sua história: a alternância entre reprodução dos modelos europeus e descoberta de um caminho próprio, de um lado, e a dicotomia entre erudito e popular, de outro. Como uma espécie de corrente subterrânea que alimenta a consciência dos artistas, críticos e ouvintes, as linhas de força vêm à tona, regularmente, pelo menos desde o século XIX. Mobilizadas por dinâmicas culturais mais amplas, de que a música é parte, ou fermentadas no campo musical, com energia para vazar sobre outros domínios da cultura, elas se manifestam de maneira dramática em alguns momentos da história. (TRAVASSOS, 2000, p.7)

Esta formulação de Elizabeth Travassos, apresentada na abertura do livro Modernismo e música brasileira, sintetiza grande parte dos debates sobre a música no Brasil. Entretanto, acredito que poderíamos acrescentar uma terceira linha de força: o embate entre "modernidade" e "tradição". Da mesma forma, creio que existe uma questão que tangencia toda a discussão, que são as distintas posturas em relação ao mercado de bens culturais. Naturalmente, este embate entre tradição e modernidade está, em alguns aspectos, relacionado com as outras duas linhas de força propostas, mas ele tem relevância por si só e é uma questão que continua atual, tal a quantidade de discursos e manifestações práticas vinculadas às ideias de "raiz" e de "autenticidade" oriundas do campo de produção. Por outro lado, o texto de Travassos encontra-se num livro sobre o modernismo, razão pela qual a autora fala em "reprodução de modelos europeus". Mas, pensando na música brasileira como um todo ao longo do século $X X$, se, nas primeiras décadas, a questão da influência estrangeira estava relacionada aos modelos europeus, especialmente àqueles oriundos da Itália, Alemanha e França, com o passar do tempo, principalmente após a 2a Guerra Mundial, a grande influência estrangeira passou a ser da música dos Estados Unidos e, depois dos anos 1960, também da Inglaterra. 
Assim, reelaborando a proposição de Travassos, podemos dizer que três linhas de força tensionam o entendimento sobre a música no Brasil e direcionam o debate: as dicotomias entre brasilidade e influências estrangeiras, entre $o$ erudito e o popular e entre modernidade e tradição. De um modo geral, estas tensões estão no centro da maioria das narrativas históricas sobre a música no Brasil. Outra questão muito presente na articulação dos discursos é a relação entre produção musical e mercado de bens culturais, por vezes considerada de maneira simplista e reducionista como relação dicotômica entre produção artística e produção comercial.

Estas questões já se encontravam presentes na formação do projeto do nacionalismo musical brasileiro, proposição estética estruturada visando a construção de uma linguagem musical nativa, brasileira, no plano da música dita erudita, artística ou de concerto. Tendo surgido de maneira ainda embrionária no final do século XIX, o nacionalismo ganhou força na década de 1920 e consolidou-se como corrente hegemônica no campo da música erudita brasileira nos anos 1930 com a liderança de Mário de Andrade, mantendo esta primazia até meados da década de 1960.0 projeto nacionalista previa a construção de uma música artística brasileira a partir da utilização do material advindo da música popular, entendida como folclore rural e urbano. Ou seja, uma música que, composta dentro dos princípios estruturais e estéticos da música europeia, seria nacional por incorporar uma sonoridade que expressasse a alma do povo brasileiro, a partir do aproveitamento dos elementos musicais que podiam ser localizados no folclore e na música popular que se desenvolvia espontaneamente. Por música popular, entretanto, os nacionalistas entendiam a música rural, folclórica, e a parcela da produção urbana que eles consideravam que ainda não havia sido deturpada pelas "influências deletérias do urbanismo" e do mercado cultural em formação. Assim, o choro e o samba considerado "autêntico" poderiam entrar na composição desta música artística brasileira, mas parte fundamental da produção musical urbana foi desconsiderada. 0 texto onde este projeto se encontra mais claramente definido e discutido em diversos aspectos é o Ensaio sobre a música brasileira, de Mário de ANDRADE (1928).

Considerando este projeto, aqui apenas esboçado em linhas muito gerais, é compreensivel que gêneros musicais que estiveram nas origens da formação da música popular no Brasil - como a modinha e o lundu, num primeiro momento, e o choro, o maxixe, o tango brasileiro e as primeiras manifestações do samba carioca - além, é claro, do folclore rural, sempre tenham sido incluidos entre os objetos de estudo das linhas mais tradicionais da musicologia histórica no Brasil. E também se pode compreender por que a música popular urbana que surge a partir da década de 1930, em estreita ligação com o mercado de bens culturais, foi considerada pela musicologia, até pelo menos a década de 1980 , como fora de sua área de interesse, indigna de estudos sérios.
Como disse Edgard MORIN, "o estudo dos fenômenos desacreditados é igualmente desacreditado; o estudo dos fenômenos julgados frívolos é igualmente frívolo" (1965).

É certo que existiram músicos que fizeram uma ponte entre a produção erudita e popular urbana, a exemplo de Radamés Gnattali. Mas foi apenas com a quebra da hegemonia do nacionalismo no campo da música artística no Brasil nos anos 1960, com a ação das vanguardas, especialmente dos compositores reunidos em torno do grupo Música Nova, e a vinculação de setores da intelectualidade com a música popular, que a musicologia começaria timidamente a tomar a sério a produção musical popular.

Desta forma, em que pese a incidência marcante da corrente nacionalista na musicologia brasileira ao longo do século $X X$, sua influência nos rumos da música popular urbana no Brasil não foi determinante e sua presença na historiografia e nos estudos musicais populares se dá de forma indireta. Se, para a música erudita, os escritos e elaborações de Mário de Andrade constituiram um programa que foi implementado na construção de uma escola de composição que foi hegemônica entre a década de 1930 e meados dos anos 1960, na música popular urbana não podemos identificar no campo de produção nenhuma corrente que se possa considerar "andradeana". José Miguel WISNIK (1983, p.105) afirma que as ideias de Mário de Andrade deixaram "marcas de influências às vezes esmagadoras sobre pelo menos três gerações de compositores". Os compositores populares não sentiram esse peso. As marcas das ideias andradeanas foram esmagadoras só para a produção da chamada música erudita ou de concerto.

Mário de Andrade tem o mérito de se encontrar entre os primeiros intelectuais do país a se ocuparem da música popular, num momento em que, mesmo no plano internacional, ela ainda não era objeto de estudo. Porém, é preciso ressaltar que a música urbana tem uma presença marginal em seus textos, pois o que ele chamava de música popular era algo diferente daquilo a que o conceito refere-se nos estudos atuais. Mário pensava na música folclórica, oriunda do meio rural, cujos elementos fossem tradicionais, autóctones, característicos do brasileiro, para alimentar a formação de uma música artística nacional; ainda que reconhecesse a existência de manifestações características de música popular que eram especificamente urbanas, como o choro e a modinha, fazia uma separação entre estas e as manifestações que chamava depreciativamente de popularescas, feitas à feição do popular, ou influenciadas pelas modas internacionais.

Ao contrário do que ocorreu no campo de produção erudito, seus escritos não influenciaram os rumos da música popular no Brasil. Assim, é uma fina ironia da História para com o projeto andradeano que nossa música popular urbana tenha se constituido numa manifestação cultural 
associada à nossa identidade nacional, e que, a partir da década de 1960, tenha atingido internacionalmente o status de produto artístico, realizando assim, por vias tortas, a proposta da construção de uma música artística autenticamente brasileira. Mas, se suas elaborações não influenciaram os rumos da produção musical, 0 mesmo não se pode dizer em relação ao pensamento sobre esta produção, pois seus textos foram e ainda são considerados no debate. Diversos pesquisadores, entre os quais se destaca José Miguel Wisnik, fizeram uma ponte entre as ideias de Mário de Andrade e os estudos sobre a música popular.

Na medida em que a musicologia e a intelectualidade acadêmica não se interessaram pelos assuntos da música popular urbana, ao mesmo tempo em que esta se constituía como um fenômeno social de grande alcance, a construção da memória e as primeiras reflexões sobre esta música se deram a partir da atuação de jornalistas, cronistas e músicos ligados direta ou indiretamente ao próprio campo de produção. Datam da década de 1930, os primeiros textos dedicados à construção de uma memória da música popular no Brasil, especialmente aquela feita no Rio de Janeiro. No ano de 1933, foram publicados dois textos fundadores de uma narrativa acerca do samba carioca: Na roda do samba, do jornalista Francisco GUIMARÃES, conhecido como Vagalume, e Samba: sua história, seus poetas, seus músicos e seus cantores, de Orestes BARBOSA. Em 1936, é lançado 0 choro: reminiscências dos chorões antigos, de Alexandre Gonçalves PINTO, conhecido como Animal, um inventário dos chorões do Rio de Janeiro de sua época, escrito num estilo simples de livro de memórias de personagens considerados relevantes na tradição do choro no Rio de Janeiro, que seria seguido por outros autores posteriores. É um caso um pouco à parte entre os memorialistas que, em sua grande maioria, estavam inventando uma tradição da música brasileira na qual o centro e expressão máxima da musicalidade nacional era o samba carioca.

Os livros de Vagalume e Orestes Barbosa apresentam duas vertentes interpretativas para o surgimento daquela que seria considerada a autêntica música do Rio de Janeiro e, por extensão, também a autêntica música brasileira, o samba. Segundo Marcos NAPOLITANO (2006, p.136),

\footnotetext{
0 debate entre Guimarães e Barbosa pode ser visto como um termômetro das sensibilidades confusas e contraditórias a respeito do tema, uma "primeira camada" de representações acerca do universo social e estético da música popular brasileira, como, por exemplo, a relação entre "samba" e "morro", que se tornou um mito fundador da nossa identidade musical. Já naquela época, as discussões sobre a música popular se pautaram ora pela busca de uma "raiz" social e étnica específica (os negros), ora pela busca de um idioma musical universalizante (a nação brasileira), base de duas linhas mestras do debate historiográfico.
}

Na narrativa de Vagalume, o samba nasceu na Bahia e de lá foi para o Rio, onde tomou vulto e desenvolveuse até tornar-se predominante. 0 autor descreve um percurso para o samba, desde uma condição primitiva no sertão da Bahia até a constituição do samba carioca, do qual o autor faz a apologia. Este samba carioca seria, em suas palavras, "filho legítimo dos morros". Mas, na sua visão, se o samba nasce "no alto do morro", morre quando "passa da boca da gente da roda para o disco da vitrola". Ou seja, para o jornalista Vagalume, o samba autêntico tende a morrer quando estabelece relações com o mercado de bens culturais. Observe-se que o discurso não é uma crítica ao mercado do samba em si, até porque, como jornalista especializado, Vagalume fazia parte deste mercado em processo de estruturação. Sua crítica dirige-se contra práticas correntes que, em seu entender, descaracterizavam o samba autêntico, tradicional, aquele oriundo da roda do samba. Este posicionamento encerra uma contradição intrínseca - entre a pureza da autenticidade e as leis do mercado - que se reproduzirá sempre que se queira manter intacta uma determinada ou suposta tradição e fazê-la circular amplamente através dos meios de comunicação massivos, ou seja, submeter o mercado aos interesses estéticos e sociais de um determinado setor.

0 grande ícone da narrativa é Sinhô, mas também merecem destaque Caninha, Eduardo das Neves, Donga, Heitor dos Prazeres e Pixinguinha. Francisco Alves é muito citado, mas de um ponto de vista crítico. Curiosamente Noel Rosa, que seria apresentado como herói em narrativas posteriores, especialmente na de Almirante, sequer é mencionado por Vagalume: seu nome aparece apenas numa lista de sambas e marchas para o carnaval de 1933 como N. Rosa. 0 nome de Noel não aparece, mas não faltam menções desabonadoras da presença de poetas no samba, considerando que isso conduziria à decadência do gênero, propondo um samba sem gramática, que não desmentisse o seu passado. Vagalume, defensor do lugar social e das características poético-musicais que ele considerava como tradicionais, concluiu seu enaltecimento do samba com um programa e um apelo em defesa do gênero. Podemos então constatar que a defesa da autenticidade do samba já atuava em 1933 - e ainda se mantém em boa forma 80 anos depois!

A narrativa de Orestes Barbosa, por outro lado, principia com a afirmação de que "o samba é carioca" e que nele "a emoção da cidade está musical e poeticamente definida". Para o autor, o carioca seria diferente em tudo, de todos os povos, e, assim sendo, "criou a sua música original". Barbosa, ao contrário de Vagalume, não se refere a uma rota do samba a partir da Bahia, nem ressalta a predominância da "roda" no surgimento de um autêntico samba carioca. Concorda com este que o samba nasce no morro, mas, para Barbosa, o samba é apropriado de diferentes maneiras pela cidade, sem que isto seja apresentado como um fato deplorável. Para o autor, já eram sambas os tangos de Ernesto Nazareth, assim como, "por medo de se dizer o vocábulo", foram chamados de "polca, lundu e maxixe todos os sambas do tempo do Imperador". Nazareth e Anacleto de Medeiros aparecem como precursores dessa música carioca e Sinhô como 
figura maior entre os sambistas já falecidos, mas sem o destaque que recebeu na narrativa de Vagalume. Segundo o autor, a música popular tomou incremento com os Oito Batutas, mas são citados inúmeros sambistas famosos do período, diluindo assim as glórias pela afirmação do gênero: Pixinguinha, Donga, Catulo, Eduardo das Neves, Francisco Alves, Mário Reis, Noel Rosa, Carmen Miranda, entre outros compositores, cantores e instrumentistas. 0 autor não faz a crítica da comercialização do samba, ao contrário, afirma que o samba tem no rádio um grande servidor. Percebe-se assim uma acepção mais ampla do gênero e uma concepção que não vê obstáculos nas relações com o mercado.

Ficam assim delineadas duas vertentes interpretativas que seriam linhas mestras na historiografia do samba. Uma narrativa é a de que foi nas rodas dos morros cariocas que 0 samba, vindo da Bahia, tomou a forma que se popularizou na cidade e, a partir daí, no resto do país. 0 crescimento e estruturação do mercado cultural seria uma ameaça para o samba que, sendo apropriado por outras camadas sociais, estaria se descaracterizando e perdendo sua razão de ser. Daí a necessidade de se defender e preservar o samba tradicional, autêntico. A outra interpretação vê o samba, ainda que tendo surgido no morro, como produto da cidade do Rio de Janeiro, da confluência de múltiplas informações culturais, uma síntese. 0 trânsito do samba por diversas camadas socioculturais, longe de constituir um problema, teria contribuído para a consagração do gênero. É curioso também observar que estas nuanças interpretativas se expressam também na forma com que estes autores legitimam o seu discurso. Sem dizê-lo explicitamente, Vagalume se apresenta como sendo "da roda do samba", tendo "informações bebidas em fontes autorizadas e insuspeitas". Já Barbosa afirma: "Eu sou da rua. Esta autoridade ninguém me negará". Apesar destas diferenciações e algumas outras nuanças, estas narrativas possuem uma grande concordância fundamental: fazem o enaltecimento, a apologia, a exaltação do samba, elegendo-o como a grande música popular brasileira.

Estes e outros textos de pessoas ligadas direta ou indiretamente ao meio musical popular - jornalistas, colecionadores, músicos e amadores - iniciaram uma literatura e uma reflexão sobre a música popular no Brasil, num momento em que os círculos mais eruditos estavam voltados para o projeto modernista, os estudos do folclore e a criação de uma música nacional artística e desinteressada, expressão utilizada por Mário de Andrade. Conforme afirma José Geraldo Vinci de MORAES (2007), "a prática iniciada na geração de Vagalume - com Jota Efegê, Almirante, Edgar de Alencar e Lúcio Rangel, entre outros - permaneceu viva, solidificou-se e desenvolveuse nas décadas seguintes, formando destacado conjunto de acervos e análises da música popular". 0 autor afirma que "sem eles, decerto a reconstrução de parte da cultura do país pela música seria muito mais complicada ou quase impossível, ainda que a maior parte dessa produção tenha sido assinalada pelo tom biográfico, impressionista e apologético, fundado em paradigma historiográfico tradicional". Moraes chama de "primeira geração de historiadores da música popular urbana" esse grupo de pesquisadores nascidos entre o final do século XIX e as primeiras décadas do XX. Para ele, "esse conjunto de autores organizou um discurso histórico organizado ao manipular todo o processo de operação historiográfica", no sentido que Michael de Certeau dá a essa expressão. Segundo Vinci de MORAES, eles definiram um lugar social, organizaram uma prática de análise e pesquisa e construíram uma narrativa, organizando assim "um autêntico discurso historiográfico sobre a música popular no Brasil" (2007). A existência desta corrente historiográfica tem sido identificada por diversos autores, que a denominam de distintas maneiras. Enor PAIANO (1994) e Clara WASSERMAN (2002), por exemplo, preferem chamá-los de folcloristas urbanos. Paulo Cesar de ARAÚJO (1999), de divulgadores da música popular.

Existem muitos pontos de contato entre este grupo e a escola do nacionalismo musical, como observa Enor Paiano. Segundo ele (PAIANO, 1994, p.68-69), ambos têm o mesmo espírito: a "paixão pelas 'coisas brasileiras'", "uma metodologia similar - recolher, organizar, compilar, mantendo a fidelidade à expressão original", bem como "um nacionalismo de caráter protetor, visando impedir a deturpação da expressão nacional, seja pela comercialização, seja pelas influências estrangeiras". A diferença principal, ainda segundo PAIANO (p.69), é que esse grupo, que ele chama de folcloristas urbanos, "não endossa o discurso modernista da superioridade artística da expressão erudita" e, "ao contrário do nacionalismo musical, que se aparelhou nos órgãos estatais e veículos dirigidos à intelectualidade", tal grupo preferiu os meios de comunicação de massa para a veiculação de suas ideias e produções, "fazendo com que estas tivessem divulgação mais ampla". A diferenciação entre estas correntes também é discutida por NAPOLITANO e WASSERMAN (2000, p.172). Para eles, "os autores preocupados com a questão da autenticidade do samba, não encontraram no pensamento musical de Mário de Andrade um apoio para estabelecer uma tradição reconhecivel e legítima para a música urbana", na qual o samba fosse "o eixo central". Teria sido "esta lacuna no pensamento folclorista de Mário de Andrade que perturbou um conjunto de criadores musicais, radialistas e jornalistas cariocas", que, a partir do final dos anos 1940, "tomaram para si a tarefa de consolidar um pensamento historiográfico sistematizado em torno da música urbana" popular.

Entre estes memorialistas, tem certo destaque a figura de Almirante (Henrique Foréis Domingues). Cantor e compositor, fundou, em 1929, o Bando de Tangarás junto com Braguinha (João de Barro), Alvinho, Henrique Brito e Noel Rosa, cuja atividade musical acompanhou até o falecimento. Radialista, trabalhou em diversas emissoras a partir de 1935, produzindo programas sobre assuntos quase sempre ligados à música popular. Almirante reuniu contribuições que pedia aos ouvintes em seus programas e 
materiais que recolhia com apurado senso de organização, para constituir um arquivo pessoal respeitável. Após a morte de Noel Rosa, dedicou-se à construção da sua memória, realizando programas de rádio, artigos em periódicos e palestras sobre o compositor de Vila Isabel. Em 1963, publicou No tempo de Noel Rosa, livro que sintetiza suas crônicas da vida de Noel, texto decisivo na invenção do mito que se formou em torno dele como herói máximo do panteão de gênios da música brasileira popular. Almirante costura uma ligação entre a música urbana, o samba, e o elemento folclórico, rural e sertanejo, entendido aqui não no sentido que o termo adquiriu nos nossos dias, mas como referência ao sertão nordestino. Destaca a figura do violonista João Teixeira Guimarães, o João Pernambuco, e sua influência no interesse que as canções folclóricas nordestinas despertaram no Rio de Janeiro na primeira década do século XX. Essas canções também teriam entrado no caldo de cultura de informações rítmicas e melódicas que concorreram na gênese do samba. Constrói assim uma narrativa que vê o samba como uma música surgida na cidade do encontro de múltiplas sonoridades e influências culturais, canalizando elementos de tradição e autenticidade.

Em 1954, o jornalista Lúcio Rangel funda, juntamente com Pérsio de Moraes, a REVISTA DA MÚSICA POPULAR (2006), publicação periódica que circulou no Rio de Janeiro, entre agosto de 1954 e setembro de 1956, com 14 edições. A revista contou com a colaboração de nomes como Almirante, Ary Barroso, Fernando Lobo, Jorge Guinle, Mariza Lira, Nestor de Holanda, Sérgio Porto e Silvio Túlio Cardoso. Publicou ainda, postumamente, artigos e discursos de Mário de Andrade. A influência da revista excedeu sua curta existência, provavelmente determinada pela intransigência e o purismo de sua linha editorial e administrativa. Maria Clara WASSERMAN (2002) realizou um estudo do papel da revista como articuladora de um debate musical voltado para a divulgação massiva dos músicos populares que, para seus editores e colaboradores, representavam a tradição da música urbana brasileira. $A$ autora cita os livros de Lúcio RANGEL e de ALMIRANTE, Sambistas \& Chorões (1962) e No tempo de Noel Rosa (1963), respectivamente, como uma compilação do pensamento que norteou o periódico. E inclui Ary VASCONCELOS (2002, p.9 e 117), embora ele não tenha sido um membro da revista, mas um colaborador esporádico, como um dos herdeiros do pensamento crítico-musical da Revista de Música Popular.

Na década de 1960, além dos citados No tempo de Noel Rosa, de Almirante e Sambista \& Chorões, de Lúcio Rangel, são publicados outros textos influentes e representativos desta linha de pensamento como as crônicas de Jota EFEGÊ (1978, 1980 e 1985) e o Panorama da Música Popular Brasileira, de Ary VASCONCELOS (1964), além dos primeiros trabalhos de José Ramos Tinhorão.

Personagem importante desta geração, o jornalista carioca João Gomes Ferreira, conhecido pelo acrônimo de Jota Efegê, teve seus artigos publicados em diversos jornais e revistas do Rio de Janeiro, a partir de 1940, reunidos pela FUNARTE em dois volumes intitulados Figuras e coisas da música popular brasileira (EFEGÊ, 1978 e 1980). A FUNARTE editou ainda mais um conjunto de crônicas de Jota EFEGÊ reunidas no livro Meninos, eu vi (1985), mas, nesse caso, o tema é a vida da cidade do Rio de Janeiro e seus personagens de uma forma mais ampla, onde a música, naturalmente, também está presente. Seus dois prefaciadores nesses livros, Ary Vasconcelos e Carlos Drummond de Andrade, ressaltam seu apuro de pesquisador diligente, sua honestidade e esmero na coleta de informações. Porém, como se tratam de crônicas escritas originariamente para jornais e revistas, elas estão marcadas pelo tom jornalístico, a narrativa está geralmente apoiada em memórias - do autor e de suas fontes - e o texto é apologético e laudatório em relação ao samba e seus heróis.

No Panorama da Música Popular Brasileira, de Ary VASCONCELOS (1964), encontra-se a periodização que se tornou clássica e muitas vezes citada em estudos sobre música popular. Inicialmente, Ary Vasconcelos delimita as épocas de acordo com momentos da história política do país, o que reflete uma concepção antiga da historiografia da música no Brasil. Assim, para ele, existe uma música popular brasileira da Colônia, do Império e da República. Nessa obra, o autor se atém ao período da República, que ele subdivide da seguinte maneira: 1) de 1889 a 1927, fase antiga, primitiva ou heróica; 2) de 1927 a 1946, fase de ouro; 3) de 1946 a 1958, fase moderna; 4) de 1958 em diante, fase contemporânea. Observe-se que a expressão "época de ouro da música popular brasileira" foi utilizada de maneira acrítica em inúmeras pesquisas acadêmicas sem a devida percepção de que ela representa uma valoração estética. Em Ary Vasconcelos, já se encontra mais delineada a atuação de historiador em relação aos trabalhos anteriores desta corrente de pesquisadores. Em obras posteriores, ele se propôs a dar conta das raízes da música popular no Brasil desde os primórdios, sem perder o foco central de suas pesquisas, que era a música urbana carioca, erigida à condição de música nacional. Ele se preocupou com a preservação da memória nas suas discografias, biografias dos personagens, mas também encontramos mais atenção na citação das fontes de suas afirmações.

Mas o principal personagem desta corrente historiográfica é José Ramos Tinhorão, que dá um passo além em relação aos pesquisadores que o antecederam na consolidação de uma narrativa para a história da música popular no Brasil, ao incorporar elementos de metodologia científica: além da pesquisa exaustiva e da citação de suas fontes, uma concepção histórico-sociológica estruturada, que orienta o seu trabalho desde os primeiros textos. Seus livros foram e ainda são influentes no debate sobre música popular e incluem-se entre aqueles trabalhos que foram seminais para as pesquisa acadêmicas. 


\section{3 - Tinhorão: de jornalista polêmico a historiador da música popular}

Nos primeiros livros da vasta obra de Tinhorão já se encontrava explicitamente definido o programa central que norteia seu pensamento. Estes textos, porém, tinham também um tom panfletário e de polêmica aberta, possuíam um caráter nitidamente militante e de intervenção, ao sabor de sua atividade de crítico musical na imprensa. Foram escritos no calor da hora, num momento em que estava em curso a modernização da música popular brasileira, contra as expectativas e propostas do autor. É o caso de Música popular: um tema em debate, lançado em 1966, livro que reuniu artigos polêmicos publicados em jornais e revistas entre 1961 e 1965.0 artigo Os pais da Bossa Nova, por exemplo, classifica a Bossa Nova como "filha de aventuras secretas de apartamento com a música norte-americana", que seria sua mãe, sendo que não se sabe quem seria o pai, da mesma forma que ocorria com muitas crianças de Copacabana, bairro onde surgiu. Nesse texto, TINHORÃO (1997, p.25-26) lista os músicos e compositores que eram mencionados pela imprensa como precursores da Bossa Nova, apresentando-os em termos depreciativos: Johnny Alf como "mulato brasileiro de nome americanizado" que disfarça seu nome verdadeiro, João Alfredo; Tom Jobim como "compositor repetidamente acusado de apropriar-se de músicas norte-americanas", também com apelido americanizado; Baden Powell como acusado de ter se apropriado de temas folclóricos que divulga com o seu nome, derivado da "admiração alienada do pai pelo general imperialista inglês criador do escotismo". E segue nessa linha.

Em 0 samba agora vai... : a farsa da música popular no exterior a polêmica já está no título. TINHORÃO (1969) desenvolve uma linha de pensamento segundo a qual, a partir da conquista do mercado internacional pelo capital norte-americano após a Segunda Guerra, "todos os países foram progressivamente levados a sufocar" suas músicas populares fundadas nas tradições de seus povos, para moldar-se ao novo estilo da música comercial norte-americana. No caso do Brasil, esse "mecanismo de dominação cultural" teria gerado "uma intervenção contínua no processo evolutivo da música urbana, tornando-se mais forte à medida que a classe média foi apropriando-se dos gêneros criados pelas camadas populares", que se nutriam do material folclórico advindo do mundo rural. Passaram a existir então vários gêneros de música popular produzida nas cidades, para atender à diversidade de gostos das distintas camadas sociais urbanas. Para o autor, "como a camada capaz de importar ou de exportar música é sempre a classe média urbana", "foi sempre a música urbana produzida ao nível das camadas alfabetizadas que se procurou fazer representar no exterior como a 'verdadeira música popular brasileira'". É a história dessa "farsa" que o autor se propõe a contar nesse livro, desde a ida de Domingos Caldas Barbosa a Portugal no século XVIII até o show da Bossa Nova no Carnegie Hall e seus desdobramentos, passando pelas incursões dos Oito Batutas e de Carmen Miranda, entre outros eventos. (p.7-10) Nesta narrativa, todos, mesmo que com eventuais boas intenções, acabaram por apresentar nossa música descaracterizada para adaptarse a padrões internacionais.

Nestes dois livros, já se encontravam esboçadas as ideias que Tinhorão desenvolveria ao longo de sua obra, mas tratam-se de textos polêmicos, de luta sem quartel com intenção de incidir no rumo dos acontecimentos. A posição que estes textos reverberavam foi derrotada no debate travado nos anos 1960 sobre os rumos que deveria tomar a música popular brasileira, na medida em que, ainda que com mediações, a atualização da música popular no Brasil e a incorporação de novas informações técnico-estéticas de fato se efetivou. ${ }^{2}$

Mas Tinhorão não se deu por vencido. Nunca reviu suas posições no debate dos anos 1960 e, ao longo de toda sua obra, buscou sustentá-las com uma argumentação fundamentada na sua pesquisa histórica, um amplo estudo da formação da música popular urbana no Brasil. Com a publicação de seu terceiro livro dedicado ao objeto, Música Popular: de índios, negros e mestiços (TINHORÃO, 1972), o autor inicia uma pesquisa histórica bem estruturada, com projeto bem definido e diligente levantamento de dados e busca de novas fontes. Desde então, ampliou significativamente os temas de seu interesse, mergulhando em questões da longa duração, observando seu objeto sob distintos aspectos e abrindo novas frentes de pesquisa. Construiu, a partir deste texto, uma vasta obra historiográfica, de grande relevância para os estudos da música no Brasil. Tinhorão abordou temas como as relações da música popular com o teatro e o cinema, com os meios tecnológicos de produção e reprodução. Estudou a presença da música popular no romance brasileiro, a forma como os autores situaram em suas histórias tipos ou episódios ligados à música popular urbana. Discutiu também a música informal e anônima feita nas ruas, a trajetória dos sons dos negros no Brasil, 0 fado como música originalmente brasileira, entre outros temas. Em 1999, defendeu dissertação de mestrado em História Social na FFLCH-USP. Tornou-se, com o tempo, um importante historiador da música brasileira popular construindo uma obra de grande fôlego.

Ao longo do tempo, Tinhorão aprimorou sua metodologia de trabalho, mas manteve-se sempre fiel ao programa apresentado no prefácio de Música Popular: um tema em debate. Sua obra representa uma importante vertente na historiografia da música popular no Brasil e se tornaria uma referência para uma história da música no Brasil, especialmente para aquelas visões que se fundamentam numa leitura "ortodoxa" do materialismo histórico. 0 autor tem o mérito inegável de expor suas concepções com toda a clareza. Conforme sua linha de pensamento inspirada no marxismo "clássico" ou "ortodoxo", segundo a qual a base determina a superestrutura, para Tinhorão, numa sociedade de classes toda a cultura é uma cultura de classes. Existiria assim uma cultura das classes 
dominantes, geralmente chamadas de "elites", e uma cultura popular, entendida como cultura das camadas mais baixas da pirâmide social. As classes médias, dentro desta lógica, não conseguiriam jamais um caráter próprio dada a sua posição nas relações de produção. De fato, segundo as leituras mais "ortodoxas" do marxismo, a classe média não tem projeto político-econômico próprio: ou apóia a burguesia e o sistema capitalista ou colocase sob a liderança do proletariado em sua luta por uma sociedade sem classes. Com um determinismo históricosociológico claramente assumido, que considera a cultura como reflexo da estrutura da sociedade determinada pelo modo de produção, sua narrativa fica inteiramente direcionada por estes pressupostos. Este raciocínio está exposto no prefácio de Música Popular: um tema em debate (TINHORÃO, 1966), no qual o autor faz, com a clareza e objetividade que caracterizam o seu texto, uma apresentação de seu programa de estudos.

$\mathrm{Na}$ introdução de Cultura Popular: temas e questões, TINHORÃO (2001) reafirma as ideias que norteiam a construção de suas interpretações histórico-sociológicas. Para o autor, a divisão da sociedade em classes, decorrente do modo de produção capitalista preservado pelas instituições do estado moderno, faz com que os homens não participem da sociedade como indivíduos, mas como membros de uma classe. Consequentemente, assumem as ideias e valores considerados próprios e bons para essa classe, o que constituiria uma ideologia, no sentido marxista do termo. Este princípio, transportado para o campo das criações alheias à produção material, como as manifestações artísticas, faz com que, no entender de Tinhorão, também esta produção projete uma ideologia. Como, nesta concepção, o modo de produção capitalista determina a divisão da sociedade em classes, toda a cultura seria então uma cultura de classes, raciocínio que se encontra também na introdução da História social da música popular brasileira.

\footnotetext{
Como os fatos historiados no livro demonstram, essa diversidade cultural é normalmente simplificada através da divisão da cultura em apenas dois planos: o da cultura das elites detentoras do poder politico-econômico e das diretrizes para os meios de comunicação - que é a cultura do dominador - e a cultura das camadas mais baixas do povo urbano e das áreas rurais, sem poder de decisão política - que é a cultura do dominado.
}

Acontece que nas nações em que a capacidade de decisão econômica não pertence inteiramente aos detentores políticos do Poder, como é o caso de paises de economia capitalista dependente - e entre eles o Brasil em estudo -, a própria cultura dominante revela-se uma cultura dominada. (TINHORÃO, 1998, p.10)

Note-se que, para o autor, a cultura das camadas pobres teria ainda que enfrentar, além da concorrência da cultura da elite, também a da classe média, que, consumidora dos produtos da indústria cultural e ligada a modelos estéticos importados, nas palavras de Tinhorão, identifica-se mais com as elites do que com o povo. Nesta linha de raciocínio, a cultura das camadas mais baixas fica submetida a uma dupla dominação: em relação à cultura das elites dirigentes do país e em relação à matriz estrangeira que domina essa cultura. Em outras palavras, a cultura das elites dominantes do país é, por sua vez, dominada por uma cultura alienígena. Em última instância, o problema da cultura seria um problema político e a única alternativa para se escapar desta agressão cultural seria a luta insurrecional contra a dominação das elites e de libertação nacional para enfrentar a reação estrangeira que tal mudança estrutural acarretaria (TINHORÃO, 1998, p.9-13).

Apoiado neste instrumental teórico, Tinhorão chegou a conclusões bastante desfavoráveis em relação a toda produção musical que não fosse aquela que se desenvolvesse como expressão das camadas mais baixas da população e que estivesse supostamente isenta de interferências da cultura dos países economicamente mais desenvolvidos.

Tinhorão foi se tornando cada vez mais respeitado na medida em que seus estudos foram ficando mais analíticos e mais consistentes em relação a dados. $A$ polêmica sempre acompanhou a sua obra, mas, num tom diferente daquele dos primeiros anos. Seus escritos dos anos 1960 encontraram muitas resistências no campo de produção e seu contraponto, no plano das ideias, está representado fundamentalmente pelo livro 0 balanço da bossa (CAMPOS, 1968), que será abordado adiante. De toda forma, a partir dos anos 1970, os textos de Tinhorão irão se constituir em parte fundamental deste esforço de pensar a história da música popular no Brasil e sua obra, ao lado dos trabalhos de José Miguel Wisnik e Arnaldo Contier, em abordagens e perspectivas muito distintas, foi um dos fundamentos para a historiografia acadêmica da música popular que iria se desenvolver a partir da década de 1980. Pode-se discordar das proposições de José Ramos Tinhorão, mas sua obra continua sendo referência nos estudos sobre a música popular e tem de ser considerada no debate, quaisquer que sejam as opiniões que se possa ter sobre seus pressupostos estético-ideológicos. Registrese também que o autor possui um estilo literário refinado, o que torna a leitura agradável mesmo que, como no meu caso, em total discordância com o conteúdo.

\section{4 - A defesa da tradição na música popular brasileira}

Os discursos destes memorialistas, jornalistas e historiadores não acadêmicos da música popular no Brasil tiveram importância decisiva na construção de um pensamento sobre esta música fortemente ancorado na ideia de um momento áureo, quando teria se expressado de maneira autêntica a alma de amplas camadas da base da pirâmide social e construído um patrimônio cultural a ser preservado das influências estrangeiras, dos interesses do mercado e dos modismos alienados da classe média. De um modo geral, estes discursos se relacionam com as discussões em torno do nacional e do popular, tão presentes no Brasil entre as décadas de 1920 e 1960, com reverberações até nossos dias. A invenção de uma tradição na música popular se insere em toda uma operação de 
invenção de uma identidade nacional, processo este que está fora do escopo deste trabalho analisar.

Em torno de uma linhagem da música popular no Brasil, que tem como eixo central o samba carioca, articulouse um conjunto de produtores musicais, um público, divulgadores, jornalistas, relações com a indústria e 0 mercado e um pensamento histórico-sociológico, que podemos pensar como um sistema que envolvia autores, obras, público, intérpretes, mercado e divulgadores, utilizando aqui, de maneira flexibilizada, a terminologia de Antonio Candido. ${ }^{3}$

Para desgosto dos puristas radicais, para os quais qualquer transformação no samba cristalizado no tempo e no espaço (o Rio de Janeiro da década de 1930) é um crime de lesa-cultura nacional, a partir da institucionalização da MPB no final dos anos 1960, constituiu-se uma linha formativa que articula três gêneros - samba, Bossa Nova e MPB - que passaram genericamente a se incluir sob o guarda-chuva da sigla MPB, como a tradição da música popular brasileira "de qualidade". Este processo formativo está estudado no trabalho de diversos autores, entre os quais Marcos NAPOLITANO (1999 e 2007) e Sean STRUOD (2007). A ideia desta linhagem como articuladora da tradição da música popular brasileira foi dominante no pensamento sobre esta música até por volta dos anos 1980 e, mesmo que perdendo força, até hoje constitui um dos parâmetros para o debate sobre a produção e recepção da música no Brasil. Um conjunto de mediadores culturais - entre intelectuais, produtores musicais, músicos, jornalistas e aficionados - foi determinante para a construção desta noção de MPB à qual se agrega a defesa de uma tradição musical que deve ser preservada como símbolo da brasilidade. Stroud demonstra a atuação destes mediadores, entre os quais inclui o estado através da atuação da FUNARTE. No caso deste estudo, que tem o foco no aspecto bibliográfico, é importante atentarmos para o papel das publicações da FUNARTE na construção de uma memória e da história da música no Brasil.

A Fundação Nacional da Arte (FUNARTE) foi criada em 1975 como parte de um conjunto de iniciativas do governo Geisel (1974-1979) em direção à promoção da cultura nacional, numa ação política voltada para uma tentativa de aproximação com artistas, intelectuais e setores da classe média insatisfeitos com o regime militar. Uma vez criado esse espaço institucional, sua atuação no terreno da música popular esteve diretamente influenciada pelas proposições apresentadas pela corrente de jornalistas e pesquisadores da música popular abordados neste texto. Estes estudiosos tinham inclusive recém se organizado na Associação de Pesquisadores da Música Popular Brasileira (APMPB) ${ }^{4}$, entidade fundada em 1975, que contou com nomes como Tinhorão, Ary Vasconcellos, Sérgio Cabral, Roberto Moura, Ruy Castro e Zuza Homem de Mello, entre outros. Durante as décadas de 1970 e 1980, a Fundação Nacional de Arte (FUNARTE) relançou os livros clássicos de Francisco Guimarães (Vagalume), Orestes
Barbosa e Alexandre Gonçalves Pinto (Animal), publicou as crônicas de Jota Efegê e diversas biografias de músicos ou personagens ligados à música popular. ${ }^{5}$ Também foram publicados diversos estudos do folclore e cultura brasileira, além de partituras de músicas de concerto esteticamente afiliadas ao nacionalismo musical. Em 1977, a FUNARTE dá início ao Projeto Pixinguinha, idealizado por Hermínio Bello de Carvalho, que, em sucessivas edições de concertos a preços populares, alcançou grandes públicos por todo o Brasil, oferecendo uma música identificada com uma certa linhagem da música popular brasileira tida como "música de qualidade". Todas estas iniciativas estavam vinculadas à ideia da preservação e divulgação das "coisas brasileiras" (STROUD, 2007).

\section{5 - Breve balanço da "linha evolutiva"}

Em artigo publicado originalmente em 1966, Caetano VELOSO polemiza abertamente com o livro de Tinhorão Música popular: um tema em debate. 0 autor ressalta que a polêmica com o livro de Tinhorão estava motivada não apenas por ser ele o único livro, até aquele momento, a colocar o tema em debate; partia também da certeza de que ele representava a sistematização de uma tendência equivocada da inteligência brasileira com relação à música popular. Caetano critica, ao longo do texto, o que considerava um discurso antimoderno em defesa da autenticidade. Argumenta que, se acompanharmos a evolução do samba até onde nos agrada ou interessa e o cristalizarmos num momento que nos pareça definitivo, podemos, por exemplo, nos ater ao samba de roda da Bahia e renegar até 0 mais primitivo partido-alto carioca (VELOSO, 1977). ${ }^{6}$ Nas discussões que se desenvolveram nas décadas seguintes, e que ainda reverberam, esta seria uma linha de argumentação fundamental contra os discursos em defesa das ideias de "autenticidade" e de "raiz" cristalizadas no samba carioca da década de 1930.

Se este artigo apareceu num veículo de circulação restrita, teve maior repercussão a participação de Caetano no debate promovido e publicado pela Revista de Civilização Brasileira (1966), intitulado Que caminhos seguir na música popular brasileira? Na sua intervenção, Caetano Veloso apresenta a ideia da linha evolutiva, que já estava esboçada em Primeira feira de balanço, como uma alternativa para se resistir ao tradicionalismo no estilo de Tinhorão, sem cair em "uma modernidade de ideia ou de forma imposta como melhoramento qualitativo" (VELOSO, 1966, p.378). A proposta da "retomada da linha evolutiva" era a de, partindo de uma compreensão do que foi a música popular brasileira até aquele momento, estabelecer "uma possibilidade seletiva como base de criação". Nesse entendimento, para se fazer algo novo dentro da tradição, dar um passo à frente, era necessário conhecê-la e senti-la. Assim, a proposta não era de ruptura com a tradição, mas de continuidade evolutiva: e como João Gilberto era, nesse entendimento, quem melhor tinha utilizado a informação da modernidade na recriação e na renovação musical, a retomada da linha evolutiva deveria 
se dar a partir de sua obra. Esta ideia de linha evolutiva da música popular brasileira tornou-se tanto uma proposta de atuação artística com desdobramentos práticos imediatos na tropicália, como uma leitura do que tinha sido até então a corrente principal da música popular urbana no Brasil. Esta proposição tem de ser entendida no contexto das discussões estéticas em curso, e como tal, um argumento a favor da modernização e incorporação de novas informações na música brasileira popular no sentido de que isso não constituiria um rompimento com a tradição, mas uma continuidade.

Entretanto, esta proposição, muitas vezes tomada como eixo articulador de discursos de caráter historiográficos, encerra uma concepção do desenvolvimento histórico da música popular no Brasil que precisa ser observada com atenção. Naturalmente, implica numa visão evolutiva e, numa seleção do repertório, numa certa linhagem da tradição que precisa ser submetida à crítica, especialmente se esta proposição for tomada como referência para se pensar a história da música popular. Ou seja, ainda que tenha servido de argumentação para se contrapor às correntes mais conservadoras e reacionárias que refutavam qualquer alteração na linguagem, a proposição da linha evolutiva também caminhou no sentido da construção de uma certa linhagem oriunda do samba como sendo a música popular brasileira.

0 mais influente dos textos em defesa da incorporação de novas informações em nossa música popular e contra as ideias nacionalistas de autenticidade e de tradição foi o livro 0 Balanço da Bossa, organizado por Augusto de CAMPOS (1968). Esse volume reunia artigos do musicólogo Brasil Rocha Brito (o mais antigo, publicado em 1960 no jornal Correio Paulistano), do maestro Júlio Medaglia e do compositor Gilberto Mendes, além dos textos do próprio Augusto de Campos. Todos estes autores pertencentes ao campo de produção erudito, mas entusiastas da música popular, "interessados numa visão evolutiva da música popular, especialmente voltados para os caminhos imprevisíveis da invenção", como podemos ler na introdução. Augusto de Campos, seu irmão Haroldo de Campos e Décio Pignatari formavam o grupo de poetas concretistas, que, juntamente com intelectuais de outras áreas, especialmente músicos como Rogério Duprat, Júlio Medaglia e Gilberto Mendes, tinham a perspectiva de uma produção artística de vanguarda cujo alcance rompesse 0 círculo restrito da arte no Brasil. Estavam sintonizados com a produção da vanguarda internacional na música e na literatura, bem como pensavam as novas questões colocadas pelo desenvolvimento da comunicação massiva. A interação de jovens músicos paulistas interessados nas linguagens da vanguarda musical - que conheceram diretamente nos festivais de Darmstadt com as proposições dos poetas concretistas esteve nas origens das concepções estéticas e da poética musical do grupo Música Nova, um dos marcos da renovação da linguagem musical no Brasil. ${ }^{7}$
Por volta de 1968, quando o Balanço da Bossa foi publicado, os irmãos Campos já tinham reconhecimento internacional, haviam publicado poemas, escritos teóricos e traduções de Ezra Pound e Vladimir Maiakovski, além do Panorama do Finnegans Wake (CAMPOS, 2001), tradução de 16 fragmentos do livro de James Joyce e estudos sobre a obra considerada um marco da literatura moderna. Também as questões da relação com o mercado eram enfrentadas pelos poetas concretistas. Décio Pignatari cunhou a expressão produssumo para designar uma arte ao mesmo tempo de produção e de consumo. Os concretistas procuraram infiltrar sua produção no mundo da comunicação de massa através de processos visuais, ligados às técnicas contemporâneas de publicidade, das manchetes de jornal às histórias em quadrinhos. $A$ incursão destes autores no universo da moderna música urbana não apenas emprestava legitimidade ao objeto, ao inserir no debate um grupo de artistas eruditos, mas colocava a discussão sobre a música popular num patamar mais elevado do que aquele por ela até então ocupado. Entretanto, assim como os livros de Tinhorão, - Balanço da Bossa era assumidamente uma peça de intervenção, com o objetivo de incidir no debate e influir nos rumos dos acontecimentos.

Os primeiros livros de Tinhorão e o Balanço da Bossa, textos de polêmica e de intervenção escritos no curso dos acontecimentos, já apresentavam em linhas gerais as duas principais vertentes de pensamento que estariam presentes nas primeiras pesquisas acadêmicas sobre música popular no Brasil, nos anos 1970 e 1980: observar o fenômeno partindo de uma análise marxista da sociedade ou buscar referências no instrumental teórico que vinha se desenvolvendo para o estudo dos novos fenômenos culturais massivos do século XX. Também alguns temas e posturas estéticas começaram a ficar delineados, como 0 estudo do samba, a defesa da autenticidade e a valorização da tradição da música popular brasileira, por um lado, e a perspectiva da modernização, da incorporação de novas tendências estéticas sem preocupações xenófobas nacionalistas, por outro.

Estes textos sintetizam a polarização das posições estéticas em jogo, mas durante a segunda metade da década de 1960, especialmente entre 1967 e 1968, diversas manifestações na grande imprensa e outros canais de comunicação colocaram intelectuais e produtores musicais no debate, com artigos publicados em veículos como o Suplemento Literário do jornal 0 Estado de S. Paulo ${ }^{8}$, Caderno B do Jornal do Brasil, a Revista Civilização Brasileira ${ }^{9}$, jornais Correio da Manhã, 0 Pasquim, entre outros. ${ }^{10} \mathrm{Um}$ dos textos de maior repercussão, neste período, também com caráter de intervenção no curso dos eventos, foi o artigo de Walnice Nogueira GALVÃO, MMPB: uma análise ideológica (1968), no qual ela critica a ideia do "dia em que virá" presente nas letras de canções da Moderna Música Popular Brasileira (MMPB), e propõe um discurso no sentido de atuação concreta para a transformação da realidade, como ocorreria, por exemplo, em Pra não dizer que não falei das 
flores, de Geraldo Vandré. Neste artigo, Galvão apresenta a percepção de que estava se conformando um subgênero dentro da música popular, que viria a ser identificado pela sigla MPB, caracterizado por uma atuação que se propunha informativa e participante, com uma proposta no plano literário de interpretação da realidade social brasileira, identificada como música de qualidade, dentro da tradição da música popular brasileira e direcionada para uma faixa de público universitário e intelectualizada.

Com o endurecimento da ditadura militar a partir da edição do Al-5 no final de 1968, o recrudescimento da repressão política e cultural e a ida dos principais personagens da cena musical para o exterior, ocorreu um arrefecimento das tensões no campo da música popular. A nova conjuntura política, estabelecida a partir de dezembro de 1968, mudou a agenda política da esquerda e de todos os setores que se opunham ao regime militar. Como resultado das lutas estéticopolíticas dos anos 1960 - que iniciam no final de 1958 com o surgimento da Bossa Nova e arrefecem em 1969 com a mudança da conjuntura política - a MPB consolidaria sua posição no cenário cultural brasileiro. Mais do que uma abreviatura para a expressão música popular brasileira, a MPB tinha incorporado uma carga estética e ideológica em seu perfil e se transformaria numa "instituição sociocultural", conforme a expressão de Marcos NAPOLITANO (1999). A música popular conquistou, neste processo, um status social de produto artístico, de parte da cultura brasileira a ser valorizada e, nesta condição, teve facilitada sua ascensão à condição de objeto passível de estudos sérios.

\section{6 - A expressão "música popular brasileira" e o acrônimo MPB}

É necessário observar mais atentamente a expressão música popular brasileira e o acrônimo MPB, em relação à cultura política nacional-popularmuito presente no Brasil dos anos 1960. Atualmente é algo aceito e plenamente incorporado pelos pesquisadores da música popular que a sigla MPB não é apenas um abreviatura de música popular brasileira. Embora a sigla MPB seja composta de suas iniciais, ela evidentemente não identifica toda a música popular feita no Brasil, mas um subconjunto desta produção. Esta sigla surgiu num determinado momento histórico, os anos 1960, para designar um repertório que emergia no calor dos festivais e que foi se configurando como um ponto de convergência entre a Bossa Nova, as canções de protesto, os gêneros tradicionais de música popular no Brasil (samba, baião, marcha) e, num momento posterior, o tropicalismo. Estava em curso um processo de redefinição e atualização da música popular no Brasil, iniciado com a Bossa Nova no final da década de 1950. Era também um momento de impasse da cultura política, articulada em torno da ideia do nacional-popular e de reorganização da indústria fotográfica e dos meios de comunicação no país. Todos estes ingredientes entraram na composição estético-ideológica daquilo que veio a ser rotulado de MPB. Vale lembrar também que o acrônimo MPB soava com uma certa similaridade com sigla política, e guardava semelhança com MDB (Movimento Democrático Brasileiro), o partido de oposição consentida no bipartidarismo imposto pelo regime militar, que tinha, naquelas circunstâncias, uma característica de frente política. Com o tempo, a sigla foi se institucionalizando e articularam-se em torno dela novas músicas que surgiam, bem como, retroativamente e com sabor de anacronismo, parte da produção anterior ao momento do seu surgimento. Assim, por mais que seja uma sigla confortável para se poupar palavras, é difícil dissociá-la deste caráter instituído.

Se a sigla MPB denomina um setor da música popular feita no Brasil, a expressão música popular brasileira já era utilizada antes da afirmação de seu acrônimo. A expressão tinha, e tem ainda hoje, um sentido agregado que se relaciona a um certo repertório, ainda que mais amplo que a posterior sigla MPB. Ou seja, falar música popular brasileira não é exatamente igual a "música popular feita no Brasil" ou "música brasileira popular": a expressão também está carregada de sentido para além do seu sentido literal. Ecoam na expressão música popular brasileira as concepções sobre o nacional e o popular, tão fortes no Brasil até os anos 1970, bem como uma visão em torno de uma certa linhagem que partiu da música popular carioca - samba-bossa-MPB - e se constituiu num processo que pode ser pensado como de invenção de tradição.

A percepção da formação da MPB como uma determinada vertente da música brasileira popular já se encontrava no texto clássico de Walnice Nogueira GALVÃO, MMPB: Uma análise ideológica, de 1968, escrito no momento em que o que viria a ser a MPB estava em gestação. Durante os anos 1990, alguns pesquisadores, entre eles Martha Tupinambá de ULHÔA (1991), Alberto MOBY (1993), Enor PAIANO (1994) e Marcos NAPOLITANO (1999), apresentaram trabalhos em que a sigla MPB foi historicizada e analisada sociologicamente.

Esta precisão no sentido da expressão MPB tem sua relevância na análise do discurso acadêmico sobre música popular no Brasil, na medida em que, dependendo da concepção que se tenha de MPB, essa generalização da sigla pode ser um indicativo da posição estéticoideológica do autor. Esta carga semântica agregada à expressão MPB não foi inventada em dado momento das pesquisas, caso no qual esta seria uma elaboração a ser refutada, o que até o momento não ocorreu. 0 que ocorreu foi a percepção de um processo histórico, através de uma análise da formação da MPB que deu sustentação teórica para uma coisa que o senso comum já conhecia: antes desta definição acadêmica do sentido de MPB, todo mundo sabia o que ia ouvir quando era convidado para ir a um bar onde tocava MPB. As pessoas tinham inclusive um indicativo do tipo de ambiente, de público e de conversa que iriam encontrar. ${ }^{11}$ 
Então, se estamos de acordo com uma definição de MPB enquanto uma "instituição sociocultural" com afinidade com uma certa cultura política e um determinado lugar social, como propõe Napolitano, podemos deduzir que sua utilização fora do contexto, anacrônica ou como sinônimo de música popular, tende a implicar uma concepção de música popular associada com aqueles elementos estético-ideológicos agregados à sigla MPB. É fato que, com o tempo, parcelas da produção musical brasileira anterior à instituição da MPB foram incorporadas a essa tradição ou linhagem de obras "de qualidade" e com "bons posicionamentos" no aspecto político-social. Mas, para um pesquisador, assumir essa incorporação de maneira acrítica indica que ele provavelmente está, consciente ou inconscientemente, em sintonia com as concepções que a sustentam.

\section{7 - Considerações finais}

Após a radicalização da ditadura militar a partir da edição do Al-5, que mudou a agenda política da esquerda, 0 debate estético-político em torno da música popular tendeu a se esvaziar. A partir dos anos 1970, temos a publicação de ensaios e das primeiras dissertações de mestrado com temáticas em torno da música popular, impulsionadas, entre outros fatores, pela reforma da pós-graduação no Brasil. As elaborações dos intelectuais sobre música popular não estavam mais direcionadas para a participação no debate estético-ideológico visando incidir nos rumos da canção popular no país, como na década anterior, pois a discussão tinha se esvaziado com o recrudescimento da ditadura militar. A canção popular emergia dos anos 1960 com status privilegiado na cultura nacional, a MPB estava institucionalizada e existia um "acordo" numa parcela do campo de produção em torná-la peça de resistência política e cultural à ditadura, o que contribuía para diluir diferenças estéticas. Neste momento, desenvolveu-se nas áreas de Letras e Comunicação uma linha de pesquisa baseada na análise do discurso do texto literário das canções, a partir da qual muitas vezes se derivavam considerações históricosociológicos. Existiram também, no período, estudos de Sociologia da Comunicação. As dissertações pioneiras apresentavam um estilo ensaístico, uma metodologia em construção, escassez de pesquisa de fontes primárias, estavam muito referenciadas na historiografia então disponivel e fortemente marcadas pelas circunstâncias da conjuntura política e pela presença do marxismo no ambiente universitário. Entretanto, têm o enorme e inegável mérito de terem pavimentado o caminho para outros pesquisadores, iniciando o processo de legitimação no campo acadêmico de um objeto até então desconsiderado. Durante os anos 1980, temos um aumento quantitativo das pesquisas, de sua distribuição por diversas disciplinas de Humanidades e inicia-se uma busca por uma metodologia mais definida para o estudo da canção. Nos anos 1990, ocorre um boom nas pesquisas e temos a consolidação dos estudos sobre a música popular no campo científico. Somente a partir de então, é que a área de Música vai incorporar a música popular como objeto de pesquisas acadêmicas. Paradoxalmente, das disciplinas das Humanidades, foi a que mais tardou em tomar a música popular como objeto de estudo. Atualmente, o tema pode ser considerado incorporado à Musicologia, embora ainda lute por um melhor posicionamento na hierarquia interna da disciplina.

Ao longo do tempo, a concepção da música popular urbana brasileira como uma linhagem articulada em torno do samba e expressa na sigla MPB e as proposições historiográficas que reverberam a ideia incorporada no conceito de linha evolutiva foram sendo submetidas à crítica. Um marco importante, neste sentido, foi a pesquisa de Paulo Cesar de ARAÚJO, Eu não sou cachorro, não: música popular cafona e ditadura militar (1999). Num trabalho que teve por objetivo analisar a produção musical chamada de "brega" ou "cafona", e discutir suas implicações com o regime militar e a censura, o autor fez uma importante revisão da historiografia que vinha até então se desenvolvendo. Segundo Araújo, "ficou cristalizada em nosso país uma memória da história musical que privilegia a obra de um grupo de cantores/ compositores", que ele considerou como sendo o "preferido das elites", "em detrimento da obra de artistas mais populares". Numa linha de argumentação que tem o caráter de polêmica aberta com a hegemonia da linhagem samba-bossa-MPB, Paulo Cesar de Araújo faz uma contundente crítica à seleção do repertório da música popular na pesquisa acadêmica, trazendo outros discursos musicais para a reflexão da história política e social.

A historiografia da música popular no Brasil em geral, e a pesquisa acadêmica em particular, privilegiou até recentemente um certo repertório, consciente ou inconscientemente. Que uma determinada pesquisa se debruce sobre um repertório específico, dentro da tradição do samba, por exemplo, é algo absolutamente normal e legítimo. Mas que o conjunto da historiografia privilegie um certo repertório, consumido apenas por uma faixa da população e em torno do qual se podem articular certas concepções sociopolítico-culturais, isso é uma questão para reflexão. Assim como na tradição da música artística europeia, no caso da música popular no Brasil, também temos nosso panteão de gênios criadores, Noel Rosa e Pixinguinha à frente, numa vertente mais tradicional, sucedidos por Tom Jobim, Chico Buarque, Caetano Veloso e Gilberto Gil, para aqueles que se orientam pela ideia da "linha evolutiva". Temos também um repertório de obras e uma sucessão de gêneros que constituem a linhagem daquilo que se entende por música popular brasileira ou MPB. No caso específico da área de Música, a tendência inicial foi privilegiar 0 repertório "popular" que apresentava mais elementos para uma análise interna do texto musical, como o choro, a Bossa Nova e a moderna música instrumental brasileira. Assim, as fontes privilegiadas nas pesquisas pioneiras, se confundiram com um repertório canônico, tendendo assim a reproduzir certos discursos e ideias, tanto acerca da música quanto da história do Brasil. 
Em minha tese de doutorado, A historiografia da música popular no Brasil (1971-1999) (BAIA, 2010), analisei detalhadamente a formação dos discursos sobre música popular no Brasil, bem como a constituição de um campo de estudos acadêmicos em torno do tema, com ênfase nas pesquisas desenvolvidas na área de História. Embora as concepções estreitas de "música popular brasileira" venham perdendo força com a incorporação de novos gêneros e abordagens no estudo da música popular, elas ainda reverberam em muitas pesquisas. A linha de frente na revisão das concepções tradicionais e de senso comum da história da música popular no Brasil tem sido as áreas de História e Ciências Sociais. Infelizmente, na área de Música não temos uma grande tradição de estudos interdisciplinares, por mais que isso esteja presente nos discursos e que se esteja caminhando positivamente nesse sentido. Muitos pesquisadores desconhecem, e alguns até mesmo veem com certa desconfiança, as elaborações desenvolvidas em outras disciplinas. Desta forma, por vezes são reproduzidos discursos históricos defasados em relação ao atual estado do conhecimento, apoiados numa bibliografia tradicional, que tem como expoente máximo José Ramos Tinhorão.

\section{Referências}

ALMIRANTE (Henrique Foréis Domingues). No tempo de Noel Rosa. São Paulo: Francisco Alves, 1963.

ANDRADE, Mario de. Ensaio sobre a música brasileira. São Paulo: Livraria Martins, 1972. Primeira edição: I. Chiarato \& Cia., 1928.

ARAÚJO, Paulo Cesar de. Eu não sou cachorro, não: música popular cafona e ditadura militar. 4a ed. Rio de Janeiro: Editora Record, 2003. Publicação da dissertação mestrado em História Eu não sou cachorro, não: memória da canção popular "cafona" (1968-1978). Rio de Janeiro: UNIRIO, 1999.

BAIA, Silvano Fernandes. A historiografia da música popular no Brasil (1971-1999). Tese de doutorado em História. São Paulo: FFLCH-USP, 2010.

BARBOSA, Orestes. Samba: sua história, seus poetas, seus músicos e seus cantores. RJ: MEC/FUNARTE, 1978. Primeira publicação em 1933.

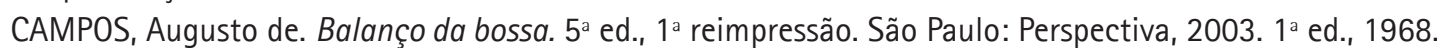

CAMPOS, Augusto de; CAMPOS, Haroldo de. Panorama do Finnegans Wake. 4a ed. São Paulo: Perspectiva, 2001.

CANDIDO, Antonio. Formação da literatura brasileira: momentos decisivos 1750-1880. 12a ed. São Paulo/Rio de Janeiro: FAPESP/Ouro sobre azul, 2009. Primeira publicação em 1957.

CONTIER, Arnaldo. Música no Brasil: História e interdisciplinaridade. Algumas interpretações (1926-1980). In: Anais do XVI Simpósio da ANPUH, 1991, p.151-189.

EFEGÊ, Jota. (João Gomes Ferreira). Figuras e coisas da música popular brasileira. Rio de Janeiro, FUNARTE, v.1, 1978; v.2, 1980. 0 v. 1 reuniu crônicas publicadas entre 1940 e 1968 (e uma de 1975), e o v.2 reuniu textos de 1970 a 1978.

Meninos, eu vi. Rio de Janeiro: FUNARTE, 1985.

GALVÃO, Walnice Nogueira. MMPB, uma análise ideológica. In: Saco de gatos: ensaios críticos. São Paulo, Livraria Duas Cidades, 1976, p.93-119. Publicado originalmente na revista Aparte, n² 2, maio-junho, 1968.

GUIMARÃES, Francisco (Vagalume). Na roda de samba. RJ: MEC/FUNARTE, 1978. Primeira publicação em 1933.

MOBY, Alberto. Sinal Fechado: a música popular brasileira sob censura (1937-1945/1969-1978). 2a ed., 2008. Publicação da dissertação de mestrado em História homônima. Niterói: UFF, 1993.

MORAES, José Geraldo Vinci de. História e historiadores da música popular no Brasil. In: Latin American Music Review, v. $28, n^{\circ} 2,2007$.

Os primeiros historiadores da música popular urbana no Brasil. In: ArtCultura. Uberlândia: EDUFU, v.8 n 13 , 2006, p.117-133.

. História e música: canção popular e conhecimento histórico. Revista Brasileira de História, n 39 . São Paulo: Humanitas, 2000, p.203-221

MORIN, Edgar. Não se conhece a canção. In: Linguagem da Cultura de Massas: televisão e canção. Coleção Novas Perspectivas em Comunicação n 6, Vozes, 1973. Artigo publicado originalmente In: Communications. France: CNRS, 1965.

NAPOLITANO, Marcos. A Síncope das idéias: a questão da tradição na música popular brasileira. São Paulo: Editora Fundação Perseu Abramo, 2007.

História e música popular: um mapa de leituras e questões. In: Revista de História. São Paulo: FFLCH-USP, n¹57, 2007, p.153-171.

A historiografia da música popular brasileira (1970-1990): síntese bibliográfica e desafios atuais da pesquisa histórica. In: ArtCultura. Uberlândia: EDUFU, v.8, n 13, 2006, p.135-150. 
Seguindo a canção: engajamento político e indústria cultural na MPB (1959-1969). São Paulo: Annablume/ FAPESP, 2001. Publicação da tese de doutorado em História: Seguindo a canção: engajamento político e indústria cultural na trajetória da música popular brasileira (1959-1969). São Paulo: FFLCH-USP, 1999.

NAPOLITANO, Marcos; WASSERMAN, Maria Clara. Desde que o samba é samba: a questão das origens no debate historiográfico sobre a música popular brasileira. In: Revista Brasileira de História: São Paulo, v.20, n 39, 2000.

PAIANO, Enor. Berimbau e o som universal: lutas culturais e indústria fonográfica nos anos 60. Dissertação de mestrado em Comunicação. São Paulo: ECA-USP, 1994.

PINTO, Alexandre Gonçalves (Animal). 0 choro: reminiscências dos chorões antigos. RJ: MEC/FUNARTE, 1978. Fac-símile da primeira edição, de 1936.

RANGEL, Lúcio. Sambistas \& chorões: aspectos e figuras da música popular brasileira. São Paulo: Francisco Alves, 1962. REVISTA DE CIVILIZAÇÃO BRASILEIRA. Que caminho seguir na música popular brasileira? Ano I, n 7, maio de 1966.

REVISTA DA MÚSICA POPULAR. Coleção completa em fac-símile: setembro de 1954-setembro de 1956. Rio de Janeiro: Bem-te-vi Produções Literárias/FUNARTE, 2006.

STROUD, Sean. The defense of tradition in Brazilian popular music: politics, culture and the creation of Música Popular Brasileira. Hampshire: Ashgate Publ., 2007. Publicação da tese de PhD Disco é Cultura: MPB and the defence of tradition in Brazilian popular music. University of London, 2005.

TINHORÃO, José Ramos. Música popular: um tema em debate. 3a ed. São Paulo: Editora 34, 1997. 1a ed.: Rio de Janeiro: Editora Saga, 1966.

O samba agora vai... : a farsa da música popular no exterior. Rio de Janeiro: JCM Editores, 1969.

Música popular: de índio, negros e mestiços. Petrópolis: Vozes, 1972.

História social da música popular brasileira. São Paulo: Editora 34, 1998. 1ª ed. portuguesa: Lisboa, Editorial Caminho, 1990.

Cultura popular: temas e questões. São Paulo: Editora 34, 2001.

TRAVASSOS, Elizabeth. Modernismo e música brasileira. Rio de Janeiro: Zahar, 2000.

ULHÔA, Martha Tupinambá de. Música popular in Montes Claros, Minas Gerais, Brazil: a study of middle-class popular music aesthetics in the 1980s. Tese de PhD. Nova York: Cornell University, 1991.

VASCONCELOS, Ary. Panorama da música popular brasileira. São Paulo: Martins, 1964.

VELOSO, Caetano. Primeira feira de balanço. In: SALOMÃO, Waly (org.). Alegria, alegria. Rio de Janeiro: Pedra \& Ronca, 1977. Publicado originalmente na revista Ângulos, da Faculdade de Direito da UFBA, 1966, p.1.

WASSERMAN, Maria Clara. Abre a cortina do passado: a Revista de Música Popular e o pensamento folclorista (Rio de Janeiro: 1954-1956). Dissertação de mestrado em História. Curitiba: UFPR, 2002.

WISNIK, José Miguel. 0 coro dos contrários: música em torno da Semana de 22. 2ª ed. São Paulo: Duas Cidades, 1983.

\section{Notas}

1 Em As Aventuras de Raul Seixas na cidade de Thor, do LP Gita, 1974, Raul Seixas colocou-se, de maneira bem humorada, fora da "linha evolutiva": / Acredite que eu não tenho nada a ver com a linha evolutiva da música popular brasileira / A única linha que eu conheço é a linha de empinar uma bandeira /.

2 Na introdução à $3^{\text {a }}$ edição de Música popular: um tema em debate, de 1997, TINHORÃO admite que "suas interpretações socioculturais vieram a cair no esquecimento desde a segunda edição do livro às vésperas de 1970". Afirma a seguir, bem ao seu estilo, que as conclusões do livro foram "sancionadas pela história dos fatos recentes da cultura de massas no Brasil, o que consagra de maneira definitiva a vitória de seu modelo de estudo pioneiro". (p.9-10)

3 Em seu estudo sobre a formação da literatura brasileira, Antonio CANDIDO distingue "manifestações literárias" de literatura propriamente dita, entendendo esta como "um sistema de obras ligadas por denominadores comuns, que permitem reconhecer as notas dominantes duma fase. Estes denominadores são, além das características internas (língua, temas, imagens), certos elementos de natureza social e psíquica, embora, literariamente organizados, que se manifestam historicamente e que fazem da literatura aspecto orgânico da civilização". Entre estes elementos Antonio CANDIDO distingue: a existência de um conjunto de produtores literários, um conjunto de receptores e um mecanismo transmissor que liga uns aos outros. 0 conjunto destes elementos dá lugar a um tipo de comunicação que se constitui como sistema simbólico. 0 processo formativo seria aquele no qual a atividade dos escritores se integra em tal sistema articulado. (CANDID0, 2009)

4 A Associação de Pesquisadores da Música Popular Brasileira (APMPB) foi fundada no primeiro Encontro de Pesquisadores da Música Popular Brasileira realizado em Curitiba em 1975. Seu $2^{\circ}$ Encontro foi realizado no ano seguinte no Rio de Janeiro, com o apoio da FUNARTE e do MEC. Outros encontros aconteceram em 1982, 1985 e o último deles em 2001. Segundo Sean STROUD, a APMPB, através de seus encontros e dos escritos de seus associados, atuou como um grupo de pressão, alertando o governo contra o que eles entendiam serem ameaças à brasilidade na música popular. Sua influência, através da atuação de seus associados, também pode ser identificada em alguns projetos governamentais, como a Política Nacional de Cultura de 1975, o Projeto Pixinguinha e as edições da FUNARTE recém-comentadas. Entretanto, sua atuação foi bastante irregular e esporádica enquanto entidade organizada, ainda que seus encontros tenham oferecido algumas das raras oportunidades de reunir escritores, acadêmicos, jornalistas, pesquisadores e músicos para discutir questões relacionadas ao campo da musica popular (STR0UD, 2005, p.54-59). 
5 Entre outros, podemos citar: LIRA, Mariza. Chiquinha Gonzaga: grande compositora brasileira. 2ª ed. Rio de Janeiro: FUNARTE, 1978; CABRAL, Sérgio. Pixinguinha: vida e obra. Rio de Janeiro: FUNARTE, 1978; SILVA, Marilia T. Barbosa da e OLIVEIRA FILHO, Arthur L. de. Pixinguinha: filho de ogum bexiguento. Rio de Janeiro, FUNARTE, 1979; MORAES, Mario. Recordações de Ary Barroso. Rio de Janeiro: FUNARTE, 1979; CAMPOS. Alice Duarte Silva de. Um certo Geraldo Pereira. Rio de Janeiro: FUNARTE, 1983; LEAL, José de Souza. João Pernambuco: a arte de um povo. Rio de Janeiro: FUNARTE, 1982; GOMES, Bruno. Custódio Mesquita: prazer em conhecê-lo. Rio de Janeiro: FUNARTE, 1986; MOURA, Roberto. Tia Ciata e a pequena África no Rio de Janeiro. Rio de Janeiro: FUNARTE, 1983.

6 Em entrevista a Luis Antônio Giron, na revista Época (n³90, nov/2005), Caetano comenta a respeito desse texto, de 1966: "Eu já tinha um lance pop tropicalista no próprio título, inspirado no anúncio de uma grande loja de departamentos em Salvador que liquidava para balanço. Foi uma utilização ready-made. Eu estudava na Faculdade de Filosofia quando alguém me pediu um artigo para a revista Ângulos, da Faculdade de Direito. A esquerda estava entusiasmada com o Tinhorão, que apoiava a xenofobia. Embora eu falasse naquele tempo mal do rock e da Jovem Guarda, 0 gérmen tropicalista estava ali."

70 grupo Música Nova constituiu-se em 1961 após a VI Bienal de Arte de São Paulo, quando os compositores Gilberto Mendes, Willy Corrêa de Oliveira, Rogério Duprat e Damiano Cozzela tiveram suas obras executadas no mesmo concerto. 0 grupo formalizou sua existência com um manifesto publicado em 1963, assinado pelos quatro compositores citados mais Régis Duprat, Júlio Medaglia, Sandino Hohagen e Alexandre Pascoal. 0 Música Nova foi um importante marco na renovação da linguagem musical no Brasil, até então hegemonizada pela estética do nacionalismo. As proposições dos poetas concretistas influenciaram diretamente tanto a estética da vanguarda erudita paulista como a formação do tropicalismo, no qual Rogério Duprat e Júlio Medaglia tiveram importante participação como arranjadores.

8 O Suplemento Literário do jornal O Estado de São Paulo circulou aos sábados entre 1956 a 1974 a partir de projeto elaborado por Antonio Candido, que indicou para seu editor Décio de Almeida Prado. Escreveram em suas páginas grandes nomes da intelectualidade brasileira, e a publicação tem relevância na história da imprensa no Brasil. A partir da reforma editorial do jornal implantada em março de 2010, o caderno Sabático tenta recuperar, de maneira atualizada, o perfil do antigo Suplemento Literário, que, de certa forma, tinha se diluído no antigo caderno Cultura.

9 A Revista Civilização Brasileira, editada pela Editora Civilização Brasileira, circulou de 1965 a 1968, quando foi fechada com a promulgação do Al-5, veículo no qual escreveram intelectuais de renome nacional e internacional.

10 Entre artigos publicados por volta de 1968, podemos mencionar: Tropicalismo! Tropicalismo! Abre a as asas sobre nós!, de Affonso Romano de Sant'Anna; o ensaio de Roberto Schwarz, Notas sobre vanguarda e conformismo, de 1967, estudo crítico sobre a tropicália, republicado em 0 pai de familia e outros estudos, no qual constava também o ensaio Cultura e política, 1964-1969; Nem toda loucura é burra, nem toda lucidez é velha, de Chico Buarque de Hollanda; $O$ universalismo e a MPB, de Sidney Miller; 0 trópico entrópico da tropicália, de Mário Chamie; 0 contexto tropicalista, de 0 . C. Louzada Filho, entre outros.

11 Está fora do escopo deste artigo discutir essa questão, mas acredito que venha ocorrendo com o tempo uma diluição desta carga semântica da sigla MPB, um alargamento de suas fronteiras estéticas com a incorporação de gêneros antes marginalizados e o esvanecimento de seu aspecto ideológico em função das grandes mudanças do contexto político-social do país. Talvez para o senso comum hoje seu sentido inicial esteja bem enfraquecido, embora não se possa colocar um sinal de igual à "música popular feita no Brasil". Ainda há uma certa expectativa do que se vai ouvir quando se é informado que, num determinado lugar, "vai tocar MPB".

Silvano Fernandes Baia é doutor em História Social pela Faculdade de Filosofia Letras e Ciências Humanas da Universidade de São Paulo (2010), mestre em Música pelo Instituto de Artes da Universidade Estadual Paulista (2005) e bacharel em Música com habilitação em violão pela mesma instituição (2001). Atualmente é professor adjunto no Instituto de Artes da Universidade Federal de Uberlândia, onde ministra disciplinas de História da Música. É membro do grupo de pesquisa interdisciplinar e interinstitucional História e Música. 